\title{
Perguntas de um graduando que lề
}

Marcelo Andrade de Azambuja² e Bruna Rossi Koerich ${ }^{3}$

Quem escreveu a pesquisa de tantas páginas?

Na capa do livro, constam o nome de doutores,

Mas degravaram eles todas as entrevistas?

E os encontros tantas vezes realizados,

Quem recebeu os palestrantes no aeroporto?

O PPG organizou um seminário.

Não o auxiliou um graduando sequer?

A professora sistematizou

suas experiências em extensão.

Experiências apenas suas?

A pós-graduação recebeu nota 7 .

Quem garantiu a produção?

Cada página uma vitória.

Quem ousou novos objetos?

A cada mês um novo artigo.

Quem arrumava as citações?

Tantas pesquisas,

Tantas questões.

1 Poema escrito em co-autoria e declamado no dia 18 de setembro de 2014, no IV Seminário de Direito, Pesquisa e Movimentos Sociais. Trata-se paródia do poema "Perguntas de um trabalhador que lê" de autoria de Bertolt Brecht.

2 Advogado popular no Rio Grande do Sul e pesquisador do IPDMS.

3 Socióloga no Rio Grande do Sul. 